\title{
An LRE (Leucine-Arginine-Glutamate)-dependent Mechanism for Adhesion of Neurons to S-laminin
}

\author{
Dale D. Hunter, ${ }^{1, a}$ Neil Cashman, ${ }^{2}$ Robin Morris-Valero, ${ }^{1}$ Joseph W. Bulock, ${ }^{3}$ Steven P. Adams, ${ }^{3}$ and \\ Joshua R. Sanes ${ }^{1}$ \\ 'Department of Anatomy and Neurobiology, Washington University School of Medicine, St. Louis, Missouri 63110, \\ ${ }^{2}$ Department of Neurology, Montreal Neurological Institute, Montreal, Quebec, Canada H3A 2B4, and ${ }^{3}$ Corporate \\ Research Laboratory, Monsanto Company, St. Louis, Missouri 63198
}

\begin{abstract}
S-laminin is a homolog of laminin that is concentrated in the synaptic cleft of the neuromuscular junction. We previously showed that the tripeptide LRE is a crucial determinant for binding of ciliary motoneurons to recombinant s-laminin. Here, we describe a neuroblastoma-spinal neuron hybrid cell line, NSC-34, that binds to an LRE-containing s-laminin fragment and to a synthetic LRE-protein conjugate. NSC-34 cells exhibit several properties of motoneurons; other cell lines tested were not motoneuron-like and did not display LRE-dependent adhesion. We therefore used NSC-34 cells to characterize the LRE-dependent adhesion mechanism. Inhibition studies with a series of 20 tripeptide LRE analogs showed that the cells exhibit a high degree of selectivity for LRE, and suggested that ligand binding requires a combination of electrostatic and hydrophobic interactions. The effects of cations on LRE-dependent adhesion are unlike those of previously described adhesion molecules including the integrins, a family of receptors for extracellular matrix proteins, including laminin. Specifically, adhesion to LRE does not require divalent cations and is inhibited by $\mathrm{Ca}^{2+}$ (but not by $\mathrm{Mg}^{2+}$ ) in the physiological range. In contrast, adhesion of NSC-34 cells to laminin is LRE- and $\mathrm{Ca}^{2+}$ independent but $\mathrm{Mg}^{2+}$ dependent, and appears to be mediated by integrins. Additionally, experiments using mixed substrates demonstrated that LRE-protein conjugates inhibit neurite outgrowth promoted by laminin. Finally, we show that, under ionic conditions that minimize integrin-dependent adhesion, NSC-34 cells bind to s-laminin-rich basal laminae in tissue sections in an LRE-dependent manner. Together, these results suggest that LRE comprises a motoneuron-selective adhesion site that is accessible in native basal laminae and that acts to inhibit neurite outgrowth.
\end{abstract}

Following nerve injury, motor axons preferentially reinnervate original synaptic sites on skeletal muscle fibers (Tello, 1907; Gutmann and Young, 1944). At these sites, the axons arborize, and their branches differentiate into functional nerve terminals.

\footnotetext{
Received June 11, 1991; revised July 23, 1991; accepted July 30, 1991.

We thank Jeanettc Cunningham for assistance. This work was supported by grants from NIH, MDA, and the Monsanto-Washington University Alliance.

Correspondence should be addressed to Joshua R. Sanes, Ph.D., Department of Anatomy and Neurobiology, Washington University School of Medicine, 660 South Euclid Avenue, St. Louis, MO 63110.

a Present address: Neuroscience Laboratories, Tufts University School of Medicine, Boston, MA 02111.

Copyright (C) 1991 Society for Neuroscience 0270-6474/91/113960-12\$05.00/0
}

From the topographic specificity of reinnervation and differentiation, it is evident that there must be factors closely associated with synaptic sites to which regenerating axons can respond. Axons selectively contact and differentiate at synaptic sites on muscle fiber basal lamina sheaths, even in the absence of muscle fibers, arguing that some of these factors are associated with basal lamina rather than (or in addition to) the muscle cell itself (Sanes et al., 1978, 1990b; Glicksman and Sanes, 1983).

In searching for such factors, we discovered s-laminin, a laminin-like glycoprotein that is concentrated in synaptic basal lamina and is adhesive to ciliary motoneurons (Hunter et al., 1989a). Then, using recombinant proteins and synthetic peptides, we mapped a motoneuron-selective adhesive site on s-laminin to a tripeptide, LRE, located $\sim 10 \mathrm{kDa}$ from the $\mathrm{C}$-terminus of the $190 \mathrm{kDa}$ protein (Hunter et al., 1989b). Subsequently, we noted that the LRE sequence is present in four proteins that are concentrated in synaptic basal lamina and for which sequence data are available: s-laminin (three occurrences in rat), the A-subunit of laminin (one occurrence in human), AChE (one occurrence each in Torpedo and human, but none in mouse), and agrin (two occurrences each in Torpedo and rat) (sequences: Sasaki et al., 1988; Hunter et al., 1989a; Rachinsky et al., 1990; Soreq et al., 1990; Rupp et al., 1991; R. Scheller, personal communication; localization: McMahan et al., 1978; Reist et al., 1987; Sanes et al., 1990a). Although LRE is expected to occur occasionally by chance alone (once per $\sim 3000-5000$ residues; Hunter et al., 1989b), its abundance in synaptic basal lamina (seven occurrences in four polypeptides totaling $\sim 8000$ residues) supports the hypothesis that it serves as ligand for motor axons. Additionally, neurotactin, a recently described neural adhesion molecule from Drosophila (Barthalay et al., 1990), contains three LREs in its short $(\sim 50 \mathrm{kDa})$ predicted extracellular domain (de la Escalera et al., 1990; Hortsch et al., 1990).

These suggestions that LRE may serve as a developmentally important recognition signal have motivated the detailed characterization of LRE-dependent adhesion that we report here. First, because ciliary ganglion cells are available in limited numbers, we sought a cell line that displayed LRE-dependent adhesion. Of several cell lines tested, the one that best met this criterion, called NSC-34, is a motoneuron-like line derived from the fusion of spinal cord neurons to neuroblastoma cells (Cashman et al., 1987). The ability of NSC-34 cells to adhere to LRE-containing peptides supports the hypothesis that the LRE-dependent system is motoneuron selective. Second, we used NSC-34 cells to characterize LRE-dependent adhesion in 
ways that are prerequisite to isolation of cellular LRE receptors. Specifically, we determined the dependence of adhesion on time, temperature, and ions, as well as its sensitivity to a large series of LRE analogs. Interestingly, the ion dependencc of adhesion not only differs from that expected for integrins (a large class of cellular receptors for extracellular matrix molecules; Akiyama et al., 1990; Albelda and Buck, 1990; Hemler, 1990), but also suggests ways in which adhesive strength might be linked to synaptic activity. Third, we asked whether LRE-containing ligands are capable of promoting process outgrowth from NSC34 cells. In fact, LRE-protein conjugates inhibit the outgrowth that laminin promotes, raising the possibility that the several LRE-containing molecules at synaptic basal lamina in muscle could cooperate in causing regenerating motor axons to stop growing at original synaptic sites. Finally, we used a "cryoculture" assay (Covault et al., 1987) to determine whether cells can adhere to native basal laminae via an LRE-dependent mechanism. We show that, under appropriate conditions, NSC-34 cells adhere selectively to s-laminin-rich areas in cryostat sections of adult rat tissue and that this adhesion is inhibited by soluble LRE. Together, these results define an apparently novel adhesion system on motoneuron-like cells that specifically recognizes LRE-containing ligands in native basal laminae and that may act to inhibit neurite outgrowth.

\section{Materials and Methods}

Cells. B35 and B104 cells were obtained from David Gottlieb (Washington University). PC12 cells, grown with or without nerve growth factor, were provided by Eugene Johnson and Pat Lampe (Washington University) (see Hunter et al., 1989b). C2 cells were provided by John Merlie (Washington University). Glomerular epithelial cells were a generous gift of David Salant (Boston University Medical School). C6 and A10 cells were purchased from American Type Culture Collection (Rockville, MD). N18TG2 cells were the gift of Marshall Nirenberg (NIH). Production of NSC-6, -19 , and -34 cells has been reported in abstract form (Cashman et al., 1987) and will be described in detail elsewhere (N. Cashman et al., unpublished observations).

Reagents. Nitrocellulose (BA85) was purchased from Schleicher and Schuell (Keene, NH). Laminin and fibronectin were from Collaborative Rescarch (Bedford, MA). A recombinant fragment of s-laminin (pETRK36) was prepared as described by Hunter et al. (1989b). Poly-L-lysine was from Sigma (St. Louis, MO). Peptides were synthesized by solidphase techniques (Barany and Merrifield, 1979) as previously described (Hunter et al., 1989b). Peptide-protein conjugates were prepared by coupling cysteinyl-peptides to keyhole limpet hemocyanin (KLH; Sigma) with $N$-succinimidyl 3-(2-pyridyldithio) propionate (SPDP; Pharmacia) according to the manufacturer's instructions.

Adhesion assays. Adhesion assays were performed as previously described (Lagenauer and Lemmon, 1987; Hunter et al., 1989b), with minor modifications. Potentially adhesive compounds were spotted onto nitrocellulose-coated wells of 12 -well tissue culture dishes, allowed to bind for $20 \mathrm{~min}$, and aspirated. The wells were rinsed with $75 \mu \mathrm{g} / \mathrm{ml}$ $\mathrm{KLH}$ in phosphate-buffered saline (PBS: $150 \mathrm{~mm} \mathrm{NaCl}$ and $15 \mathrm{~mm}$ sodium phosphate, $\mathrm{pH}$ 7.2) and then incubated with $750 \mu \mathrm{g} / \mathrm{ml} \mathrm{KLH}$ in PBS for $1 \mathrm{hr}$ at room temperature. After two rinses with PBS, $0.2-$ $0.4 \mathrm{ml}$ of adhesion medium was added to each well. Initial screening of cell lines used Dulbecco's Modified Eagle's Medium containing 10 $\mathrm{mg} / \mathrm{ml}$ bovine serum albumin (BSA). For most of the assays on NSC34 cells (including those illustrated in Figs. 1-4, 6-8), the adhesion medium consisted of $\mathrm{Ca}^{2+}$ - and $\mathrm{Mg}^{2+}$-free Hanks' Balanced Salt Solution supplemented with $0.8 \mathrm{~mm} \mathrm{MgCl}_{2}, 2 \mathrm{mg} / \mathrm{ml} \mathrm{NaHCO}$, and $10 \mathrm{mg} / \mathrm{ml}$ BSA. Modifications to this medium are noted in the text. The plates were brought to $37^{\circ} \mathrm{C}$, and 40,000 cells were added to each well, bringing the total volume of medium to $0.5 \mathrm{ml}$. Except as noted in figure captions, the plates were then incubated for $90 \mathrm{~min}$ at $37^{\circ} \mathrm{C}$ in a humidified incubator with a $5 \% \mathrm{CO}_{2}, 95 \%$ air atmosphere. Subsequently, unbound cells were removed by two rinses in PBS that had been warmed to $37^{\circ} \mathrm{C}$ Finally, bound cells were fixed in $2 \%$ glutaraldehyde plus $2 \%$ paraformaldehyde in PBS. Because the absolute number of cells bound varied among assays, we present data from representative experiments, but repeated each experiment several times with qualitatively similar results.

Cryoculture assays were performed as described in Covault et al. (1987). Briefly, pieces of adult rat kidney were frozen in liquid nitrogencooled isopentane and sectioned at $5 \mu \mathrm{m}$ in a cryostat. Sections were mounted on $12 \mathrm{~mm}$ ethanol-sterilized coverslips, which were then placed in the wells of 24-well cluster dishes. NSC-34 cells were suspended at $10^{5}$ per $\mathrm{ml}$ in Hanks' Balanced Salt Solution, supplemented with $10 \mathrm{mg} /$ $\mathrm{ml}$ BSA and $2 \mathrm{mg} / \mathrm{ml} \mathrm{NaHCO}$, and $0.5 \mathrm{ml}$ was added to each well. The dishes were incubated at $37^{\circ} \mathrm{C}$ for $1 \mathrm{hr}$, then washed and fixed as described above.

\section{Results}

\section{LRE-dependent adhesion of motoneuron-like cells}

We showed previously that a bacterially produced, $20 \mathrm{kDa}$ C-terminal fragment of s-laminin is adhesive for neurons from chick ciliary ganglia. Ciliary neurons were used because they form cholinergic neuromuscular junctions on striated muscle fibers in vivo, and thus are motoneurons. The s-laminin fragment pET-RK36 contains the sequence LRE, and neuronal adhesion to it is inhibited by soluble LRE. Other neuronal types tested did not bind to the LRE-containing s-laminin fragment, and LRE did not inhibit attachment of ciliary neurons to non-LREcontaining substrates. Together, these results defined LRE as a major determinant of a motoneuron-selective attachment site on an s-laminin-derived polypeptide and implied that motoneurons bear an LRE receptor (Hunter et al., 1989b).

Because ciliary neurons are available in limited quantity, we began the present study by seeking a cell line that displayed LRE-dependent adhesion. To this end, we tested the binding of several cell lines to pET-RK36 and to laminin in a short-term assay of cell adhesion. Tissue culture dishes were coated with a thin nitrocellulose film (Lagenaur and Lemmon, 1987) and then with a potentially adhesive protein. Free sites were blocked with BSA or $\mathrm{KLH}$, and cells were incubated over the substrata for $90 \mathrm{~min}$ at $37^{\circ} \mathrm{C}$. The plates were then washed, and the adherent cells were counted (see Materials and Methods for details). Cells of several lines adhered well to laminin in this assay, but did not adhere detectably to pET-RK36. These included PC12 rat pheochromocytoma cells, which resemble adrenal chromaffin and/or sympathetic cells (Tischler and Greene, 1975); B35 and B104 cells, which are neuron-like cells derived from chemically induced brain tumors in rats (Schubert et al., 1974, 1986); C6 rat glioma cells (Benda et al., 1968); C2 murine myogenic cells (Yaffe and Saxel, 1977); A10 rat aorta-derived smooth musclelike cells (Kimes and Brandt, 1976); GEC rat renal glomerular epithelial cells (Kreisverg et al., 1978; Quigg et al., 1988); and N18TG2 murine neuroblastoma cells (Minna et al., 1972).

Of all cell lines tested, only one adhered well to pET-RK36. This line was derived from the polyethylene glycol-mediated fusion of embryonic murine spinal cord neurons with N18TG2 neuroblastoma cells. Forty clonal cell lines were isolated from this fusion; several of them exhibited neuron-like propertics (Cashman et al., 1987), and one, NSC-34, resembles spinal motoneurons.in several respects (see Discussion). We tested three of these lines, NSC-6, NSC-19, and NSC-34. All adhered well to laminin (Fig. 1a). However, few NSC-6 or NSC-19 cells attached to pET-RK36 in our short-term adhesion assay. In contrast, a large fraction of NSC-34 cells, up to $\sim 50 \%$ in some assays, attached to pET-RK36 (Fig. 1b). This adhesion was specific in that it was inhibited by a monoclonal antibody to s-laminin; anti-s-laminin did not inhibit adhesion to other substrates such as fibronectin or laminin, and a control antibody 

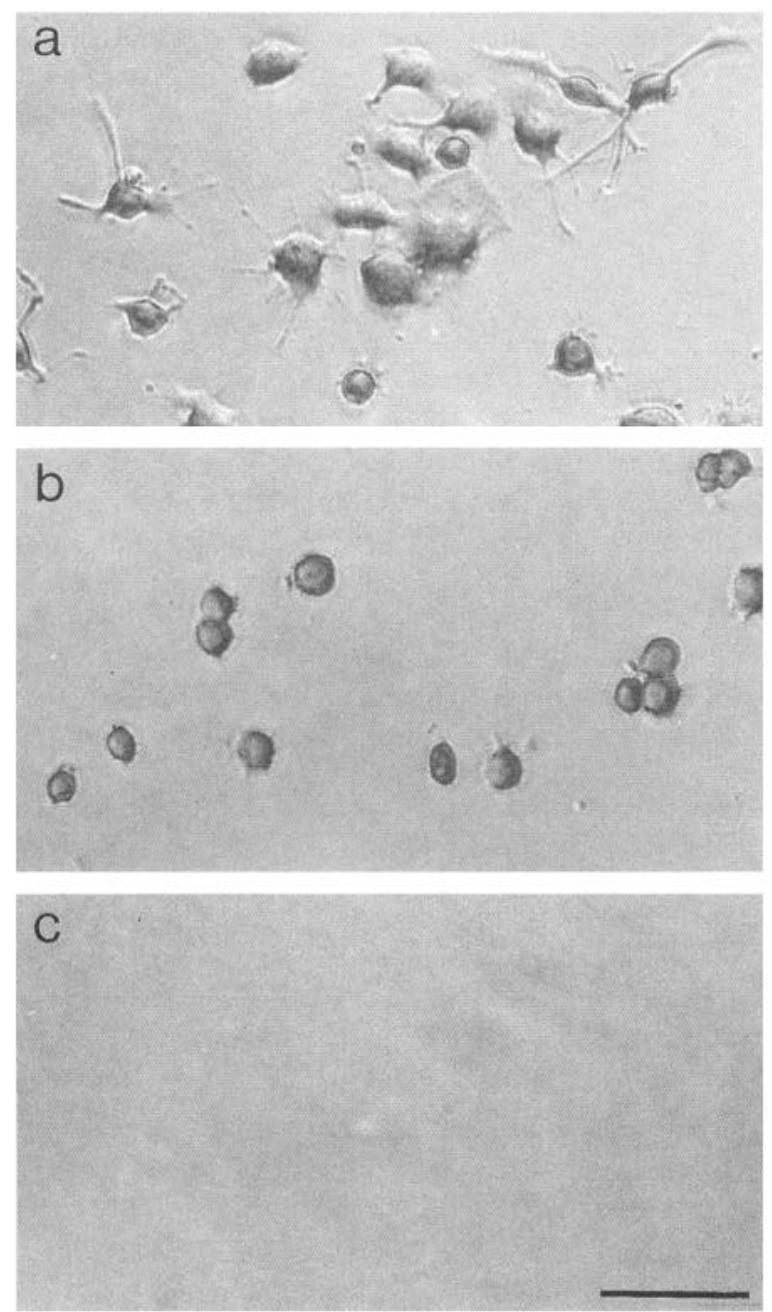

Figure 1. Adhesion of NSC-34 motoneuron-like cells to nitrocellulose coated with laminin $(a)$, the recombinant s-laminin fragment pET-RK36 (b), or the inert "blocking" protein KLH (c). Cells were incubated in coated tissue culture dishes for $90 \mathrm{~min}$, and then unbound cells were washed off and bound cells were fixed and photographed under phase optics. Scale bar, $100 \mu \mathrm{m}$.

did not inhibit adhesion to pET-RK36 (Fig. 2a). In addition, NSC-34 cells did not adhere significantly to KLH alone (Figs. $1 c, 2 a)$. Adhesion to both laminin and pET-RK36 was complete in $90 \mathrm{~min}$ at $37^{\circ} \mathrm{C}$ (Fig. $2 b$ ); however, cells spread on laminin but remained rounded on pET-RK36 (Fig. $1 a, b$; see also below).

Two observations demonstrated that adhesion of NSC-34 cells to pET-RK36 is mediated by specific, protein-associated cell surface receptors. First, adhesion to laminin and to pET$\mathrm{RK} 36$ was prevented by lowering the temperature to $4^{\circ} \mathrm{C}$, whereas NSC-34 cells adhered to poly-L-lysine comparably well at $4^{\circ} \mathrm{C}$ and $37^{\circ} \mathrm{C}$ (Fig. 2 c). Second, treatment of NSC-34 cells with trypsin abolished their ability to adhere to laminin or pETRK36 but not to poly-L-lysine; reincubation in trypsin-free medium for 4-6 hr restored the cells' adhesive properties (data not shown). Thus, adhesion to laminin and to pET-RK36 was "active" by the criteria of Grinnell (1978) and Turner and Flier (1989) in that it appeared to be energy dependent and mediated by cell surface receptors; in contrast, adhesion to poly-L-lysine was "passive" by these criteria.

We tested the LRE dependence of the adhesion of NSC-34
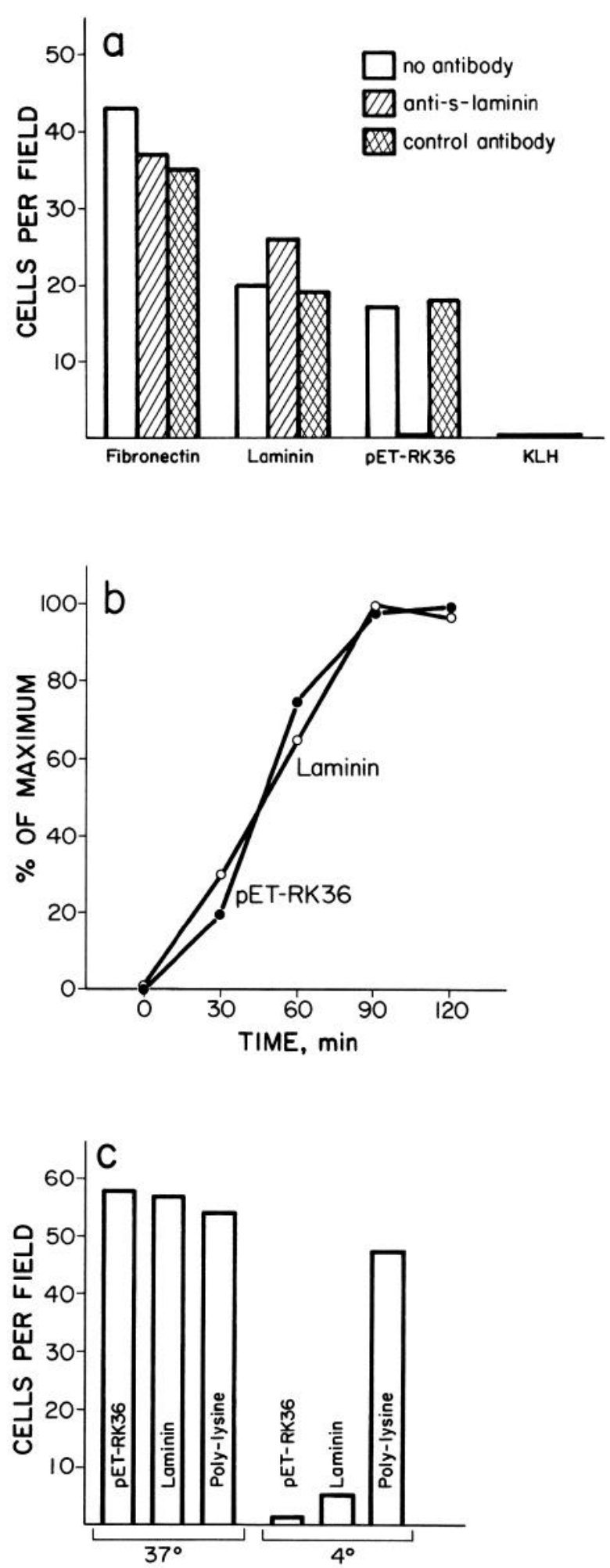

Figure 2. Adhesion of NSC-34 cells to pET-RK36 is specific, rapid, and active. $a$, Anti-s-laminin monoclonal antibody D5 inhibits adhesion to pET-RK36 but not to laminin or fibronectin. An irrelevant monoclonal antibody of the same class (C14; Sanes and Chiu, 1983) is inactive, and no adhesion to $\mathrm{KLH}$ is detectable. $b$, Adhesion to both pET-RK 36 and laminin is detectable in $30 \mathrm{~min}$ and complete by 90 min under the conditions used. $c$, Fewer cells adhere either to pETRK36 or to laminin at $4^{\circ} \mathrm{C}$ than at $37^{\circ} \mathrm{C}$. In contrast, adhesion to polyL-lysine is similar at $4^{\circ} \mathrm{C}$ and $37^{\circ} \mathrm{C}$. 

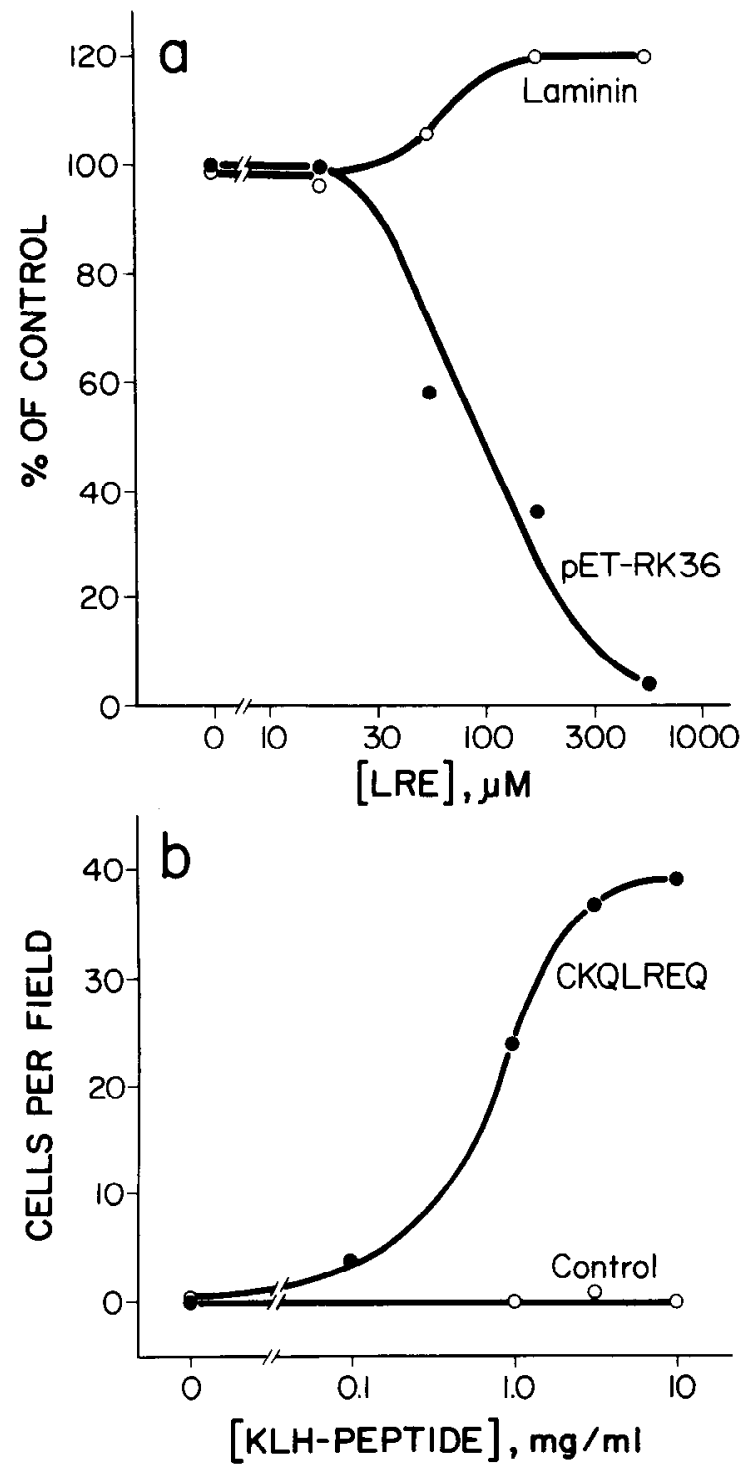

Figure 3. NSC-34 cells use an LRE-dependent adhesion mechanism. $a$, Soluble LRE inhibits adhesion to pET-RK36, but has no marked effect on adhesion to laminin. $b$, NSC-34 cells adhere to KLH that had been coupled to an I.RE-containing peptide (KI.H-CKQLREQ; solid circles); a control KLH-peptide conjugate (KLH-RYAAPVNRRKSRC; open circles) and KLH alone (see Fig. $2 a$ ) are inactive.

cells to pET-RK36 in two ways. First, we asked whether soluble LRE inhibited adhesion. Indeed, LRE did block adhesion when added to the culture medium, with $>90 \%$ inhibition at $\sim 500$ $\mu \mathrm{M}$ and an $\mathrm{IC}_{50}$ of $\sim 80 \mu \mathrm{M}$ (Fig. $3 a$ ). These concentrations are about two- to threefold higher than those that inhibited adhesion of ciliary neurons to pET-RK36 (Hunter et al., 1989b). LRE had no consistent effect on adhesion of NSC-34 cells to laminin (Fig. $3 a$; see also Fig. $4 b$ ), indicating that the action of the peptide was specific and did not interfere generally with NSC-34 metabolism or integrity. Second, we tested the ability of NSC-34 cells to bind to nitrocellulose coated with either of two LREprotein conjugates (KQLREQ coupled to KLH via a cysteinyl residue added to the peptide's $\mathrm{C}$ - or $\mathrm{N}$-terminus). Cells bound to both conjugates in a dose-dependent fashion, whereas no binding was seen to $\mathrm{KLH}$ alone or to a conjugate of KLH with an irrelevant peptide (Fig. $3 b$ ). Thus, NSC-34 cells are capable

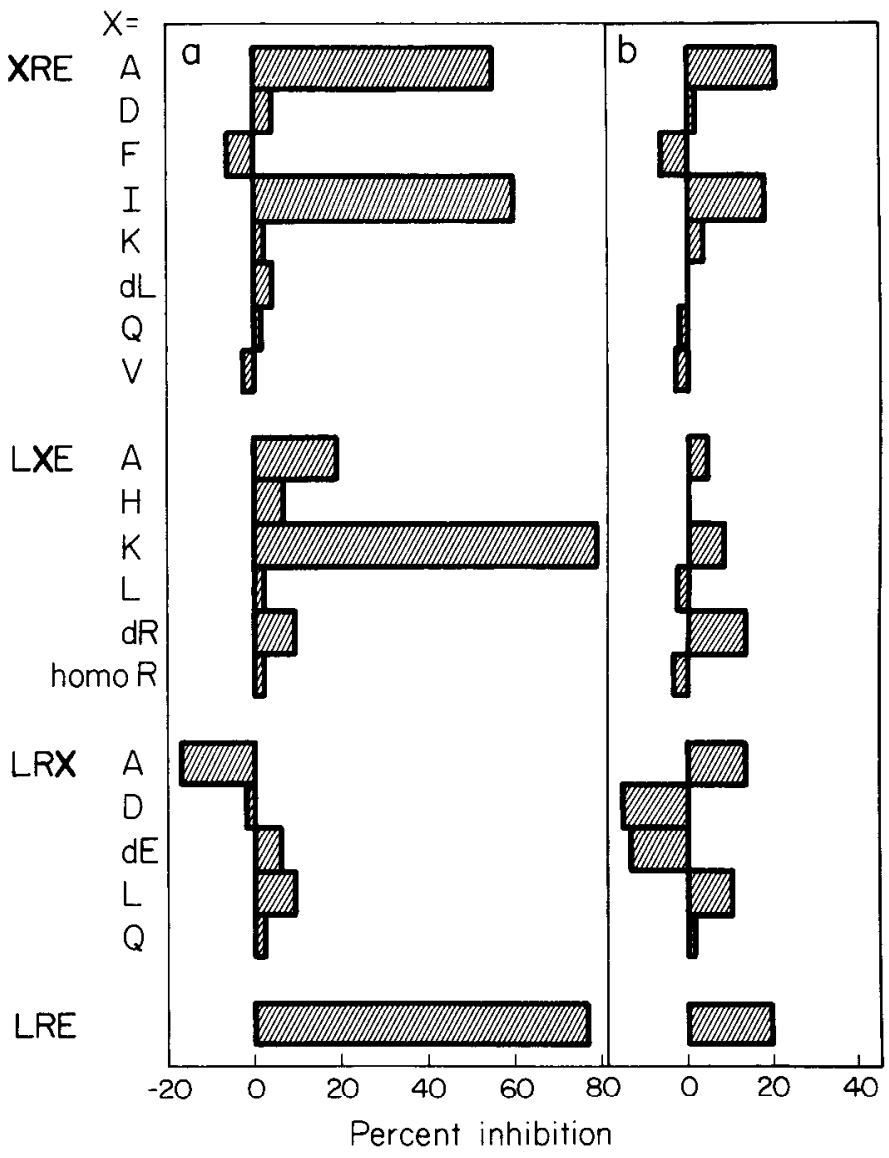

Figure 4. Stereoselectivity of the LRE-dependent adhesion mechanism. Adhesion of NSC-34 cells to pET-RK36 $(a)$ or to laminin $(b)$ was measured in control medium or in the presence of $100 \mu \mathrm{g} / \mathrm{ml}(\sim 200$ $\mu \mathrm{M})$ of the indicated LRE-related tripeptides. $X$ indicates the position of the residue substituted. None of the peptides inhibited adhesion to laminin significantly $(<20 \%)$, whereas ARE, IRE, and LKE, as well as LRE, reduced adhesion to $\mathrm{pET}-\mathrm{RK} 36$ by $>50 \%$. $d$ prefix indicates dextro form. Values are means of four separate experiments, each of which included duplicate measurements.

of specific LRE-dependent adhesion to LRE-containing substrata.

\section{Selectivity of the LRE receptor}

To assess the selectivity of the LRE-dependent adhesion system, we synthesized and tested a series of tripeptide LRE analogs in which each residue was systematically replaced by other amino acids. The tripeptides were dissolved in medium, and their ability to inhibit adhesion of NSC-34 cells to pET-RK36- or laminin-coated substrata was assayed. Initially, the peptides were tested at $100 \mu \mathrm{g} / \mathrm{ml}$, or $\sim 200 \mu \mathrm{M}$; this concentration of LRE is sufficient to inhibit adhesion of NSC-34 cells to pET-RK 36 by $\sim 80 \%$ and is twice the concentration required for $50 \%$ inhibition (Fig. $3 a$ ). At this concentration, only 3 of the 19 analogs testedARE, IRE, and LKE-significantly inhibited adhesion to pETRK36 (Fig. $4 a$ ). In each case, the inhibition was specific, in that adhesion to laminin was not significantly affected (Fig. $4 b$ ). Doseresponse curves indicated that the $\mathrm{IC}_{50}$ values were $\sim 800 \mu \mathrm{M}$ for ARE and IRE and $\sim 200 \mu \mathrm{M}$ for LKE; thus, these analogs were approximately $10 \%$ and $50 \%$ as effective as LRE by this measure. Of the other 16 analogs, 15 inhibited adhesion to pETRK 36 by $<10 \%$ at $200 \mu \mathrm{M}$ and are thus likely to be at least 
sixfold less effective than LRE ( $10 \%$ inhibition at $\sim 30 \mu \mathrm{M})$. The remaining analog, LAE, inhibited adhesion by $\sim 15 \%$ at 200 $\mu \mathrm{M}$; we do not know if this inhibition is specific.

Our interpretation of these results is that LRE-dependent adhesion involves a cellular receptor that recognizes specific features of each residue in the tripeptide. When leucine is replaced by isoleucine or alanine in the first position, a partial but significant decrease in activity is observed. Both of these residues are similar to leucine in terms of their hydrophobic and conformational properties, but differ in their precise shapes. Interestingly, replacement with valine, which has similar hydrophobicity but different conformational propensities, results in an inactive compound. Conformational and/or stereochemical requirements in this position are further corroborated by the observation that the D-leucine replacement was inactive. In the second position, the positive charge presented by the guanidinogroup of arginine is clearly important for activity, in that the only replacement that retains activity is lysine, which bears a positive charge on its $\epsilon$-amine group. The position of this positive charge is apparently critical, as reflected in the inactivity of the homo-arginine derivative, which has one less methylene group than arginine between its peptide backbone and guanidino-group. Again, the stereochemistry at this position is important, as D-arginine is inactive. Finally, the importance of the glutamate residue is demonstrated by the findings that conservative substitutions that retain charge (aspartate) are isosteric and able to form hydrogen bonds (glutamine), or simply have different stereochemistry (D-glutamate), are all inactive.

In summary, the cellular LRE receptor apparently binds to its ligand by a combination of electrostatic and hydrophobic interactions, such that the charge and shape of each of the three residues must be maintained for proper recognition. In these respects, the selectivity of the LRE receptor for LRE resembles that of some integrins for the RGD sequence that comprises a crucial determinant of cell-binding site in several extracellular matrix molecules (Ruoslahti and Pierschbacher, 1987). In both cases, the receptor recognizes a tripeptide domain on a macromolecule, the recognition has strict stereochemical requirements, and the binding site is formed by the conjunction of a positive, a negative, and a hydrophobic residue.

\section{Ionic requirements of LRE-dependent adhesion}

Recent molecular biological analyses have revealed that many cell adhesion molecules can be classified into a small number of families; members of each family have related sequences and are thought to be evolutionary relatives as well (Albelda and Buck, 1990). In addition, some such families have distinctive requirements for divalent ions. Thus, the cadherins require calcium ions to function effectively (Takeichi, 1988), integrins generally require magnesium or calcium ions (Dransfield and Hogg, 1989; Loftus et al., 1990), and the immunoglobulin superfamily members are cation independent (Edelman, 1988). To learn whether the cellular LRE receptor might belong to one of these families of adhesion molecules, we asked whether adhesion of NSC-34 cells to pET-RK36 is cation dependent.

In the first experiment of this series, adhesion to fibronectin, laminin, and pET-RK 36 was assayed in medium that contained $1.8 \mathrm{mM} \mathrm{Ca}^{2+}$ and $0.8 \mathrm{mM} \mathrm{Mg}^{2+}$, in the same medium plus 5 mM EDTA to reduce the concentrations of free $\mathrm{Ca}^{2+}$ and $\mathrm{Mg}^{2+}$ to $<0.1 \mu \mathrm{M}$, and in the EDTA-containing medium supplemented with $20 \mathrm{mM} \mathrm{Mg}^{2+}$ (Fig. 5a). Addition of EDTA completely abolished adhesion of NSC-34 cells to fibronectin and laminin; adhesion was completely restored when excess $\mathrm{Mg}^{2+}$ was added back. These results are consistent with a large body of data showing that many cells, including neurons, use $\mathrm{Mg}^{2+}$ dependent integrins to adhere to these extracellular matrix molecules (Albelda and Buck, 1990; Hemler, 1990; Reichardt and Tomaselli, 1991). In contrast, more cells adhered to pET-RK36 in the presence of EDTA than in its absence, and this potentiation was not greatly affected by the presence of excess $\mathrm{Mg}^{2+}$. Thus, adhesion to pET-RK36 did not require $\mathrm{Mg}^{2+}$ or $\mathrm{Ca}^{2+}$ at $\geq 1 \mu \mathrm{M}$ and appeared to be inhibited by "physiological" concentrations of $\mathrm{Ca}^{2+}$.

Based on these results, we varied the concentrations of $\mathrm{Mg}^{2+}$ and $\mathrm{Ca}^{2+}$ systematically to test their effects on adhesion. Adhesion of NSC-34 cells to laminin required $\mathrm{Mg}^{2+}$ ions at $>0.1$ mM, whether or not $\mathrm{Ca}^{2+}$ was present, but was unaffected by $\mathrm{Ca}^{2+}$, whether or not $\mathrm{Mg}^{2+}$ was present (Fig. $5 b, d$ ). In contrast, adhesion to pET-RK36 was $\mathrm{Mg}^{2+}$ independent whether or not $\mathrm{Ca}^{2+}$ was present but was inhibited by $\mathrm{Ca}^{2+}$ whether or not $\mathrm{Mg}^{2+}$ was present (Fig. 5c,d). The degree of inhibition varied somewhat from experiment to experiment, but was generally $\sim 50 \%$ at $0.3-0.5 \mathrm{~mm}$ and sometimes reached $80 \%$ at $1-3 \mathrm{~mm}$ (Fig. $5 d$ ).

Two general classes of mechanism can be envisioned by which $\mathrm{Ca}^{2+}$ might inhibit adhesion of cells to pET-RK36. In one, the affinity of the receptor-ligand interaction differs depending on whether or not $\mathrm{Ca}^{2+}$ is bound to some element of the adhesion mechanism, for example, the substrate, the cellular LRE receptor, or another cell surface component. In these cases, inhibition by $\mathrm{Ca}^{2+}$ would be expected to be readily reversible. Alternatively, the presence of $\mathrm{Ca}^{2+}$ might reduce the number of cellular binding sites or substrate molecules available for adhesion, for example, by activating a $\mathrm{Ca}^{2+}$-dependent protease that degrades the substrate or the LRE receptor, or by inducing internalization of the receptor. In these cases, inhibition by $\mathrm{Ca}^{2+}$ would be irreversible, at least until the cells could regenerate new surface components. To distinguish these alternatives, we exposed either the NSC-34 cells or the substrate (pET-RK36) to $5 \mathrm{~mm}$ calcium for $90 \mathrm{~min}$, then chelated excess $\mathrm{Ca}^{2+}$ with EDTA before measuring adhesion during the subsequent $90 \mathrm{~min}$. In no case did preincubation with $\mathrm{Ca}^{2+}$ detectably affect adhesion; that is, equal numbers of NSC-34 cells adhered to pET-RK 36 regardless of whether the cells, the substrate, both, or neither had been preincubated with $\mathrm{Ca}^{2+}$ directly before addition of EDTA (data not shown). Thus, inhibition of binding by $\mathrm{Ca}^{2+}$ is readily reversible. Furthermore, binding of NSC-34 cells to the LREprotein conjugate (KLH-CKQLREQ) was inhibited by $\mathrm{Ca}^{2+}$ (data not shown); because it is unlikely that the conformation of this substrate is markedly $\mathrm{Ca}^{2+}$ dependent, this result suggests that $\mathrm{Ca}^{2+}$ acts by binding to the cells rather than to the substrate. Together, these results are most consistent with the idea that calcium ions modulate the affinity of a cellular LRE receptor for pET-RK36.

\section{Effects of LRE-dependent adhesion on neurite outgrowth}

Laminin is a potent promoter of neurite outgrowth (Sanes, 1989), and laminin-derived peptides have been shown to bear outgrowth-promoting activity (Tashiro et al., 1989; Beck et al., 1990). It was therefore interesting to ask whether LRE-dependent adhesion might affect process outgrowth. As shown above, we were able to use a relatively short LRE-containing peptide (CKQLREQ), coupled to a carrier protein, as a substrate for adhesion. To assay the effects of this peptide on neurite out- 

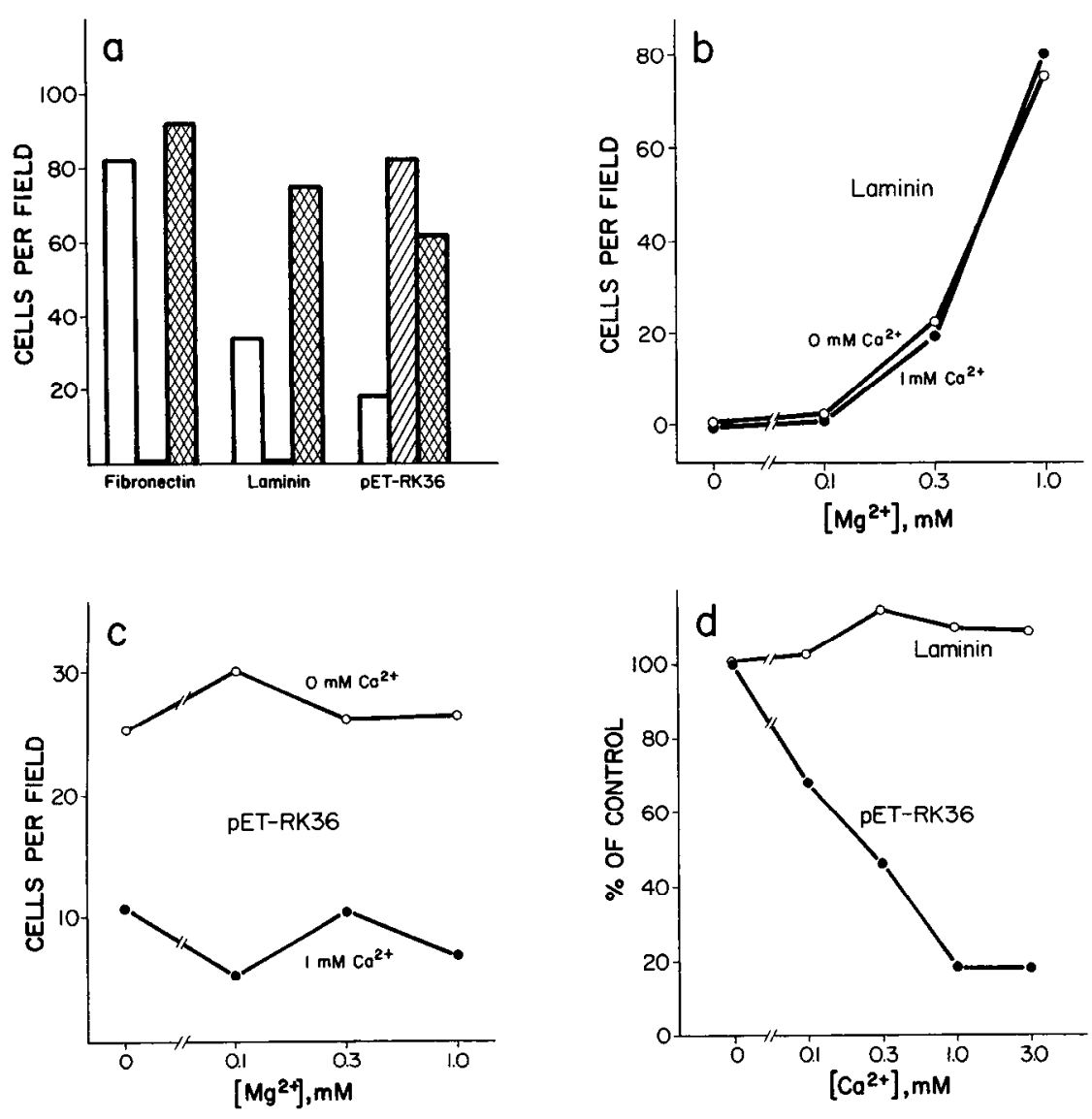

Figure 5. Cation dependence of the adhesion of NSC-34 cells to pET-RK 36 and to laminin. $a$, Adhesion was measured in medium containing $1.8 \mathrm{~mm}$ $\mathrm{Ca}^{2+}$ and $0.8 \mathrm{mM} \mathrm{Mg}^{2+}$ (open bars), in the same medium to which 5 mM EDTA had been added (hatched bars), or in the EDTA-containing medium to which $20 \mathrm{mM} \mathrm{Mg}{ }^{2+}$ had been added (crosshatched bars). Adhesion to laminin (and to fibronectin) was inhibited by chelation of divalent cations, whereas adhesion to pET-RK 36 was enhanced. The inhibition but not the enhancement was reversed by readdition of $\mathrm{Mg}^{2+} . b$, Adhesion to laminin is $\mathrm{Mg}^{2+}$ dependent, in the presence or absence of $1 \mathrm{~mm} \mathrm{Ca}^{2+}$. $c$, Adhesion to pET-RK36 is unaffected by $\mathrm{Mg}^{2+}$, in the presence or absence of $1 \mathrm{mM} \mathrm{Ca}^{2+}, d$, In the presence of 0.8 $\mathrm{mM} \mathrm{Mg}^{2+}$, adhesion to pET-RK36 is inhibited by $\mathrm{Ca}^{21}$, whereas adhesion to laminin is unaffected by $\mathrm{Ca}^{2+}$. growth, we examined the morphology of NSC-34 cells plated on laminin, KLH-CKQLREQ, and mixtures of the two.

Representative ficlds of NSC-34 cells plated on pET-RK36, the KLH-CKQLREQ conjugate, or laminin are shown in Figure 6. Some cells adhered to all substrates within $30 \mathrm{~min}$; the cells remained rounded on pET-RK36 (Fig. 6a) or KLH-KQLREQ (not shown) but spread rapidly on laminin (Fig. 6b). By $90 \mathrm{~min}$, processes had begun to appear on laminin, whereas cells plated on the s-laminin fragment or peptide remained rounded and bore no processes (Fig. 6c,d). By $180 \mathrm{~min}$, the different effects of the substrata were marked (Fig. $6 e, f$ ). These results show that, although KLH-CKQLREQ, pET-RK36, and laminin all support adhesion, only laminin supports rapid process outgrowth.

In order to determine whether the s-laminin peptide inhibited process outgrowth, rather than merely failing to support it, we examined outgrowth on laminin substrates overlaid with $\mathrm{KLH}-$ peptide conjugates. The striking result was that KLH-CKQLREQ inhibited process outgrowth on laminin, whereas a control KLHpcptide conjugate and KLH alone were without detectable effect (Figs. $6 g, h ; 7 b$ ). A concentration-effect curve for KLHCKQLREQ indicates that it inhibited process outgrowth in the same range of concentrations that promoted adhesion (Fig. 7c; cf. Fig. $3 b$ ). Because the KLH-peptide conjugates were added to surfaces that were already coated with laminin, the effects observed cannot be attributed to competition between laminin and KLH-peptide for binding sites on the nitrocellulose substrate. Additionally, similar numbers of cells adhered to all substrata (Fig. 7a), indicating that the reduction in the number of cells with processes reflects a reduction in the percent of adherent cells with processes, rather than a reduction in total adhesion. Thus, activation of the LRE receptor appears to inhibit outgrowth on laminin.

\section{LRE-dependent adhesion to native basal laminae}

The experiments reported thus far involve adhesion of cells to LRE-containing recombinant proteins or synthetic peptides that are derived from the primary sequence of s-laminin. An important issue that this work does not address is whether LRE is exposed and active in the environments that neurons or neurites actually encounter in vivo. In fact, some adhesive sites demonstrable on fragments of laminin are now believed to be inaccessible or "latent" in the native molecule (Nurcombe et al., 1989), and others may be masked in the complexes that laminin forms with other matrix molecules (e.g., Muir et al., 1989).

To address this issue, we used a "cryoculture" assay in which cells are plated on cryostat sections of unfixed adult tissues (Covault et al., 1987). We previously showed that neurites of chick ciliary neurons grow along basal laminae in several tissues in this assay, and that the neurites stop growing at synaptic sites on sections of skeletal muscle. For the present work, we used adult kidney as a source of tissue, because sections of renal cortex contain large, easily discerned areas of glomerular basal laminae, which are rich in s-laminin, as well as large areas of tubular basal laminae, which are devoid of s-laminin (Fig. $8 a, b$; Hunter et al., 1989a; Sanes et al., 1990).

When NSC-34 cells were plated on cryostat sections of rat kidney in $\mathrm{Mg}^{2+}$-containing culture medium and incubated at 

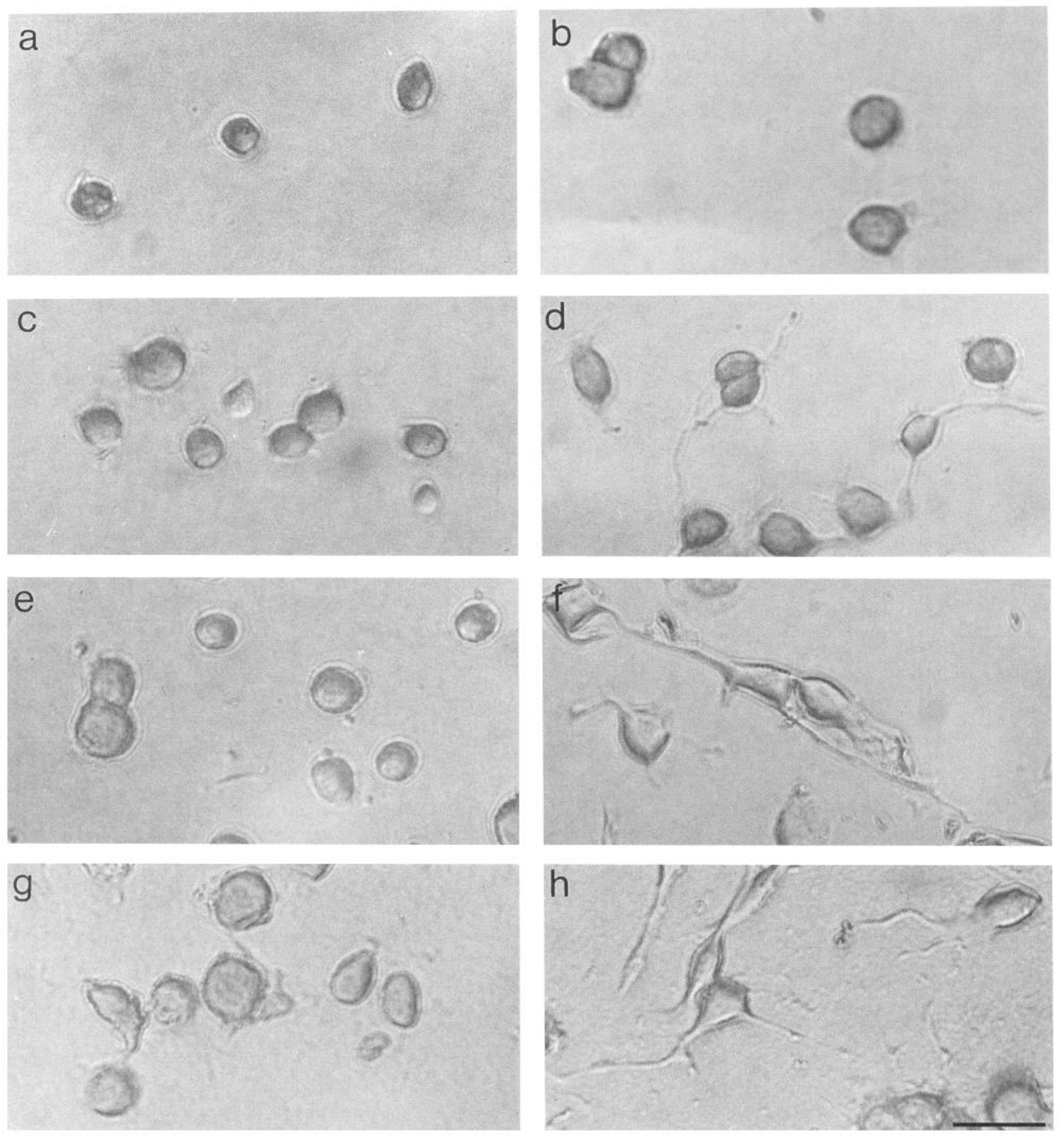

Figure 6. Substrate-dependent process outgrowth from NSC-34 cells. Cells were incubated on pET-RK36 $(a, c, e)$, laminin $(b, d, f)$, laminin overlaid with KLH-CKQLREQ $(g)$, or laminin overlaid with KLH-RYAAPVNRRKSRC $(h)$. After $30(a, b), 90(c, d)$, or 180 min $(e-h)$, unbound cells were rinsed off and bound cells were photographed. NSC-34 cells extended processes on laminin but not on pET-RK36. KLH-CKQLREQ inhibited the process outgrowth that laminin promoted, whereas the control KLH-peptide conjugate was inactive. Cells plated on KLH-CKQLREQ alone were indistinguishable in morphology from those plated on pET-RK36. Scale bar, $100 \mu \mathrm{m}$.

$37^{\circ} \mathrm{C}$ for $1 \mathrm{hr}$, numerous cells adhered to both tubules and glomeruli (Fig. $8 c, d$ ). In contrast, when the cells were incubated in $\mathrm{Ca}^{2+}$ - and $\mathrm{Mg}^{2+}$-free medium, many cells adhered to glomeruli but few adhered to tubules (Fig. $8 e, f$ ). In the assay illustrated in Figure $8 e$ and $f$, for example, the density of bound cells was $39.7 \pm 4.8$ per $\mathrm{mm}^{2}$ over glomeruli and $2.04 \pm 0.24$ per $\mathrm{mm}^{2}$ over tubules (mean \pm SEM for $1510 \times$ microscope fields), or a 20-fold "preference" for glomeruli. Qualitatively similar results were obtained in five separate experiments, although the absolute number of adherent cells varied from experiment to experiment. In light of the studies on ion dependence detailed above, a reasonable explanation of this result is that adhesion to laminin-rich tubular basal lamina is mediated by $\mathrm{Mg}^{2+}$-requiring integrins, whereas adhesion to s-laminin-rich glomerular basal lamina is mediated at least in part by an $\mathrm{Mg}^{2+}$-independent, $\mathrm{Ca}^{2+}$-inhibited LRE receptor. To test this idea, we assayed the adhesion of NSC-34 cells to cryostat sections in the presence of LRE. LRE had no discernible effect on adhesion in 
control medium (not shown), but almost completely blocked the preferential adhesion of cells to glomeruli in $\mathrm{Ca}^{2+}$ and $\mathrm{Mg}^{2+}$ free medium (Fig. $8 g, h$; in this experiment, the "preference" of neurons for glomeruli over tubules was 1.6-fold in the presence of LRE, compared to 20-fold in its absence). Thus, NSC-34 cells can adhere to native basal laminae via an LRE-dependent mechanism, indicating that LRE-like ligands are accessible and active in native basal laminae.

\section{Discussion}

We have characterized the binding of NSC-34 cclls to pETRK36, a $20 \mathrm{kDa}$, LRE-containing fragment of s-laminin. Adhesion appears to depend critically on the LRE sequence within the fragment, in that it is inhibited by soluble LRE and mimicked by substrata coated with an LRE-protein conjugate. The LRE-dependent adhesion system is "active" (temperature dependent), protein associated (protease sensitive), stereochemically specific (as determined by use of a panel of LRE analogs), and capable of recognizing ligands in native basal laminae (as shown in the cryoculture assay). All of these features support the idea that NSC-34 cells bear a specific receptor that recognizes the LRE tripeptide within proteins. NSC-34 cells are a promising source for the isolation of LRE receptors, and the pharmacological analysis presented here (e.g., on the ionic dependence and stereochemical features of the binding) will be useful in assessing whether LRE-binding moieties correspond to the physiological receptor.

\section{LRE-dependent adhesion of motoneuron-like cells}

Of 10 cell lines tested, the only one that displayed robust LREdependent adhesion was NSC-34. In independent experiments, which will be detailed elsewhere (N. R. Cashman et al., unpublished observations), NSC-34 cells were shown to differ from their N18TG2 parents in ways that suggest they may have been derived from a spinal motoneuron. In brief, NSC-34 cells (1) express high levels of ChAT, (2) synthesize and store ACh, (3) release $\mathrm{ACh}$ in response to depolarization, (4) express cell surface antigens that are also present on cultured primary motoneurons, and (5) form morphologically stable contacts with and induce contractile activity in cocultured myotubes. In short, of many cell lines tested, the one that adheres best to pET-RK36 is the one that exhibits several properties of motoneurons.

The finding that NSC-34 cells exhibit LRE-dependent adhesion supports our previous suggestion that LRE comprises a motoneuron-selective attachment site on s-laminin. So far, the only other cells that we have found to be capable of LREdependent adhesion are chick ciliary neurons, which innervate striated muscle in vivo and thus are motoneurons (Hunter et al., 1989b). Other primary cells tested, as well as other cell lines, do not adhere appreciably to LRE-containing s-laminin fragments, even under conditions where they bind well to laminin. Moreover, although it is a somewhat circular argument, the observation that NSC-34 cells bear an LRE-dependent adhesion system supports the contention that they are motoneuron-de-

Figure 7. Inhibition of process outgrowth from NSC-34 cells by an LRE-protein conjugate. $a$ and $b$. Cells were incubated for $180 \mathrm{~min}$ on the indicated substrates, and then unbound cells were rinsed off and bound cells were counted and scored for process outgrowth. Values are averaged from two experiments; similar results were obtained in three additional experiments. Processes were counted if they were more than
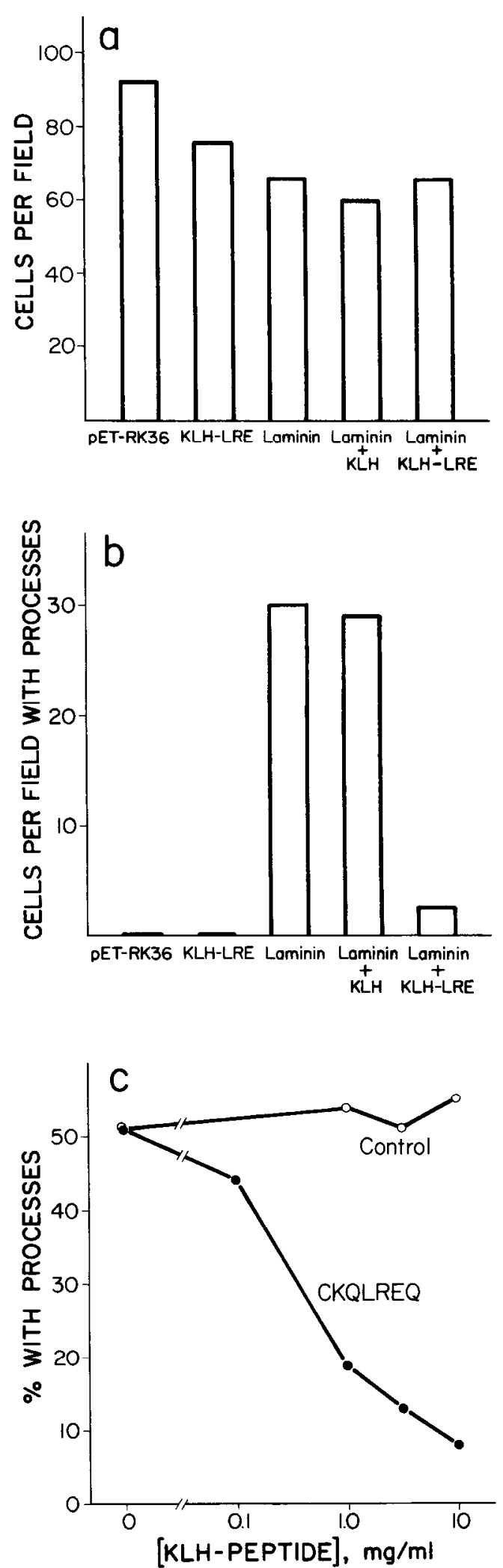

one cell body diameter in length. $a$, Similar numbers of cells adhered to all substrates tested. $b$, Many cells extended processes on laminin overlaid with KLH, whereas few cells extended processes on pET-RK36, KLH-CKOLREQ, or laminin overlaid with KLH-CKOLREQ. $c$, In another experiment, laminin was overlaid with varying concentrations of KLH-CKQLREQ or KLH-RYAAPVNRRKSRC (control). The LREcontaining conjugate inhibited process outgrowth at $1 \mathrm{mg} / \mathrm{ml}$, whereas the control conjugate was without effect at $10 \mathrm{mg} / \mathrm{ml}$. 

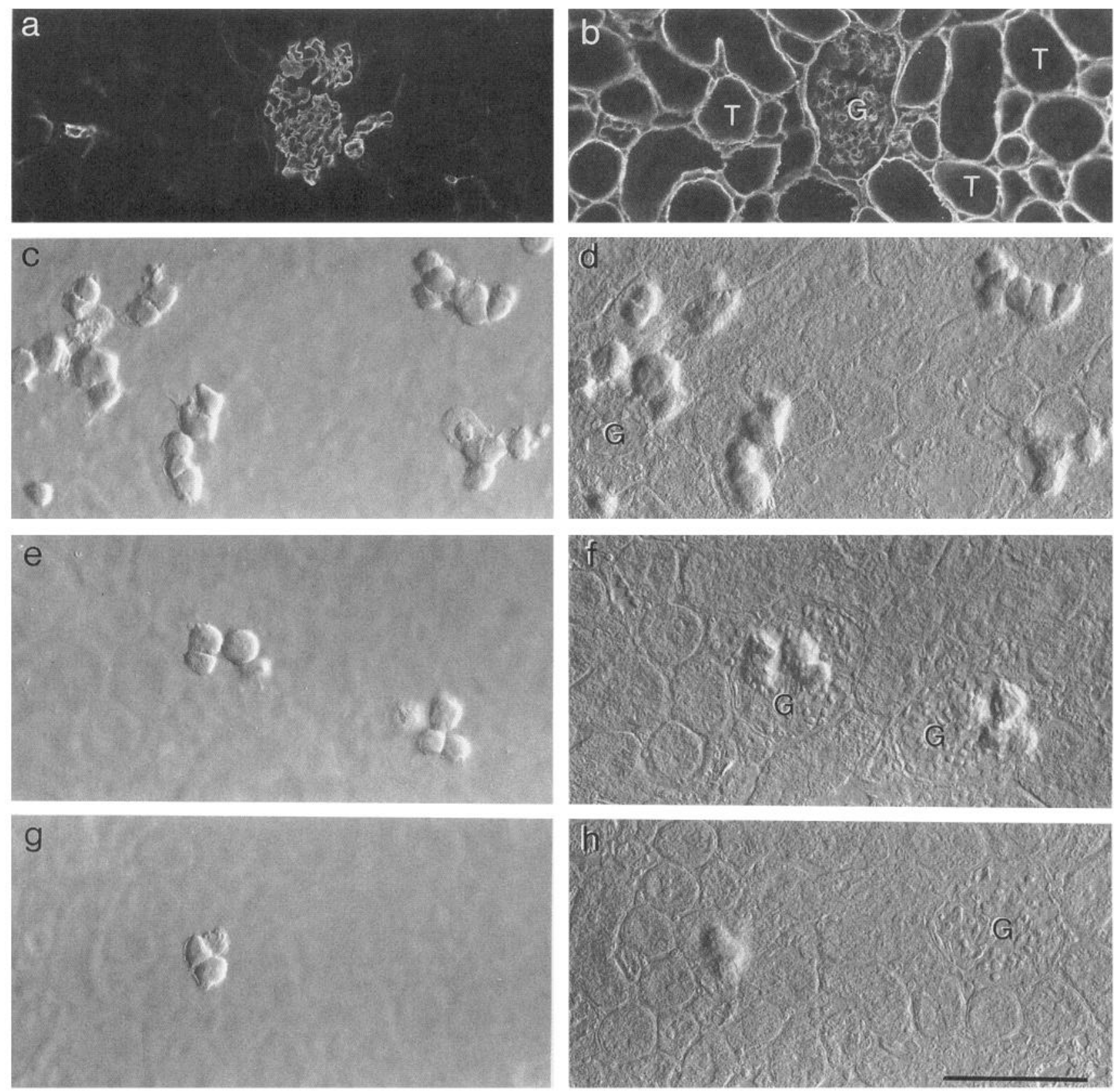

Figure 8. Attachment of NSC-34 cells to cryostat sections of kidney in the "cryoculture" assay. $a$ and $b$, This section was double labeled with a monoclonal antibody to s-laminin $(a)$ and a polyclonal antibody to laminin $(b)$, plus appropriate second antibodies, to show that glomeruli $(G)$ have s-laminin-rich basal laminae, whereas tubules $(T)$ have s-laminin-poor basal laminae. Tubules and glomeruli are easily distinguished with Nomarski optics in $d, f$, and $h . c$ and $d$, Adhesion in $\mathrm{Mg}^{2+}$-containing medium. Cells adhere to both tubules and glomeruli. $e$ and $f$, Adhesion in $\mathrm{Mg}^{2+}$ - and $\mathrm{Ca}^{2+}$-free medium. Many more cells adhere to glomeruli than to tubules. $g$ and $h$, Adhesion in $\mathrm{Mg}^{2+}-$ and $\mathrm{Ca}^{2+}-$ free medium in the presence of $200 \mu \mathrm{M}$ LRE. Adhesion to glomeruli is reduced. Both micrographs in each pair show the same field; the first ( $c, e, g$ ) is focused on the cells, while the second $(d, f, h)$ is focused on the section. Fewer cells than usual are attached in $c$ and $d$; this field was chosen to permit visualization of the underlying section. Scale bar, $100 \mu \mathrm{m}$.

rived cells. On the other hand, some points of uncertainty prevent unqualified acceptance of three conclusions. First, we have not yet shown that adhesion to native s-laminin is LRE dependent. To do so will require elucidation of the oligomeric structure of s-laminin and preparation of pure s-laminin under nondenaturing conditions; these studies are in progress (Engvall et al., 1990; Green et al., 1990). Second, we have not yet demonstrated LRE-dependent adhesion of primary spinal motoneurons. Finally, in that s-laminin is present in several extra- muscular basal laminae (Sanes et al., 1990a) and in developing cortex (Sanes et al., 1990b), it is reasonable to expect that other cell types will be found that recognize it. In fact, we have recently shown that some photoreceptors adhere to pET-RK36 (Hunter et al., 1990). Nonetheless, it remains attractive to speculate that the LRE receptor, when isolated, will prove to be a motoneuronspecific marker within defined regions of the nervous system, and that motoneurons will prove to be capable of interactions with native s-laminin. 


\section{Inhibition of LRE-dependent adhesion by calcium ions}

Because several families of adhesion receptors have distinctive requirements for divalent cations, we studicd the cffects of $\mathrm{Mg}^{2+}$ and $\mathrm{Ca}^{2+}$ on the LRE-dependent adhesion system. Results presented in Figure 5 indicate that adhesion is unaffected by $\mathrm{Mg}^{2+}$ and inhibited by $\mathrm{Ca}^{2+}$. These results are noteworthy in two respects. First, they suggest that the cellular LRE receptor is not one of the previously characterized members of the integrin superfamily. We had suspected that integrins might mediate adhesion to LRE because integrins serve as receptors for several extracellular matrix molecules, because several different integrins have been implicated in the adhesion of neurons to laminin, and because some integrins are known to recognize short peptide determinants (e.g., RGD) in their ligands (Ruoslahti and Pierschbacher, 1987). However, although patterns of divalent cation dependence vary considerably among integrins, all those studied to date require millimolar concentrations of a divalent cation, most are able to use $\mathbf{M g}^{2+}$ for adhesion, and none arc inhibited by $\mathrm{Ca}^{2+}$ in the absence of other divalent cations (Dransfield and Hogg, 1989; Albelda and Buck, 1990; Hemler, 1990; Loftus et al., 1990; Reichardt and Tomaselli, 1991; but see Lallier and Bronner-Fraser, 1990, for one possible exception). Furthermore, an antibody to the chick integrin $\beta_{1}$ subunit, JG22 (Greve and Gottlieb, 1982), inhibits adhesion of chick ciliary neurons to laminin but not to pET-RK36 (data not shown; antibodies to murine integrins were not available for tests of NSC-34 cells). While definitive classification of the LRE receptor awaits its purification, our results to date are not consistent with its assignment to any heretofore described family of adhesion molecules, including the integrins.

Second, the inhibition of LRE-dependent adhesion by $\mathrm{Ca}^{2+}$ occurs in the physiological range (the concentration of $\mathrm{Ca}^{2+}$ is $0.5-2 \mathrm{~mm}$ in most culture media, and $\sim 1 \mathrm{~mm}$ in serum) and might therefore be physiologically relevant. For example, theoretical calculations (Attwell and Ilcs, 1979) and measurements in vivo (Krnjevic et al., 1982; see also Betz et al., 1989) suggest that extracellular $\mathrm{Ca}^{2+}$ concentrations may fall near synapses consequent to $\mathrm{Ca}^{2+}$ influx during synaptic transmission (but see Ginsburg and Rahamimoff, 1983). If such local decreases in $\left[\mathrm{Ca}^{2+}\right]_{0}$ occurred during development, they might lead to strengthening of LRE-dependent adhesion. Interestingly, NSC34 cells that bind to pET-RK36 in the absence of $\mathrm{Ca}^{2}$ ' remain attached when $\mathrm{Ca}^{2+}$ is subsequently added back to the medium (B. Porter and J. R. Sanes, unpublished observations), suggesting that LRE-dependent adhesion may become $\mathrm{Ca}^{2+}$ insensitive (or be supplanted by a $\mathrm{Ca}^{2+}$-insensitive mechanism) following an initial phase of attachment. Thus, a transient decrease in $\left[\mathrm{Ca}^{2+}\right]_{0}$ could result in a long-lasting increment in adhesion that in turn could lead to stabilization and/or maturation of the synapse, a consequent increase in the strength of synaptic transmission, a further increment in LRE-dependent adhesion, and so on. In this way, the LRE receptor could provide a mechanism for the known activity dependence of synaptic strength (e.g., Shatz, 1990).

\section{Inhibition of process outgrowth by LRE-containing ligands}

Experiments in which laminin and LRE-containing peptides were mixed indicate that occupancy of the LRE receptor inhibits process outgrowth promoted by laminin (Figs. 7, 8). These results provide the first clue to the functional consequences of LRE-dependent adhesion. However, a variety of processes could result in an apparent inhibition of neurite outgrowth (Patterson, 1988; Muir et al., 1989; Keynes and Cook, 1990; Schwab, 1990), and further experiments will be required to distinguish among them. For example, activation of an LRE-dependent system could prevent the initiation of neurites, decrease their rate of elongation, or cause their retraction. These alternatives can be distinguished by studying process outgrowth on patterned substrates (cf. Letourneau, 1975), for example, by asking whether neurites growing on laminin stop at, cross onto, or turn away from stripes on which laminin is overlaid with $\mathrm{KLH}-\mathrm{CKQLREQ}$ or s-laminin. Additionally, "stripe" experiments could, in principle, reveal whether interaction with LRE affects the local differentiation of a growing neurite into a nerve terminal, as either a cause or an effect of growth inhibition. Such experiments are perhaps better performed with ciliary neurons than with NSC34 cells, because the neurites, terminal specializations, and synapses that ciliary neurons form in vitro have been characterized in detail (e.g., Covault et al., 1987; Dubinsky and Fischbach, 1990; Lupa et al., 1990). In fact, preliminary experiments have revealed that LRE-containing ligands can inhibit outgrowth from ciliary neurons, as they do from NSC-34 cells (Weis et al., 1989). Experiments to study the basis of this inhibition are now in progress.

\section{A possible role for the $L R E$-dependent adhesion system in neuromuscular interactions}

Our interest in the LRE-dependent adhesion system stems from studies that indicated that components of the basal lamina at the neuromuscular junction direct the preferential reinnervation of original synaptic sites by regenerating motor axons (Sanes et al., 1978). We previously showed that s-laminin is concentrated in synaptic basal lamina (Hunter et al., 1989a), and that LRE is a crucial determinant of an adhesion site on an s-lamininderived fragment (Hunter et al., 1989b). Here, we have documented three features of LRE-dependent adhesion that support the notion that it plays a role in the interactions of motor axons with the synaptic cleft. (1) LRE-dependent adhesion is apparently motoneuron selective: it is displayed by two motoneuronlike cell types, ciliary motoneurons and NSC-34 cells, but not by any of a variety of other primary cells or cell lines tested. Correspondingly, motor axons can innervate or reinnervate striated muscle fibers, whereas other intramuscular axons (sensory and sympathetic) apparently cannot. (2) LRE-rich substrata not only fail to promote outgrowth from NSC-34 cells, but appear to inhibit outgrowth promoted by laminin. During reinnervation, many terminal branches of motor axons do not grow beyond synaptic sites, but instead differentiate there into nerve terminals. (3) Cells can adhere to s-laminin-rich areas in unfixed tissue sections via their LRE-dependent system, thus demonstrating that the LRE sequence is exposed and active in native basal laminae. Together with the observation that at least four proteins concentrated in synaptic basal lamina contain the LRE sequence (see introductory remarks), these results support the hypothesis that binding of an LRE receptor on motor axons to LRE at synaptic sites may mediate nerve-muscle interactions important for the formation and/or maintenance of synapses.

\section{References}

Akiyama SK, Nagata K, Yamada KM (1990) Cell surface receptors for extracellular matrix components. Biochim Biophys $\Lambda$ cta 1031: 91-110. 
Albelda SM, Buck CA (1990) Integrins and other cell adhesion molecules. FASEB J 4:2868-2878.

Attwell D, Iles JF (1979) Synaptic transmission: ion concentration changes in the synaptic cleft. Proc R Soc Lond [Biol] 206:115-131.

Barany G, Merrifield RB (1979) Solid phase peptide analysis. In: The peptides: analysis, synthesis, biology, Vol 2 (Gross E, Meienhofer J, eds), pp 1-284. New York: Academic.

Barthalay Y, Hipeau-Jacquotte R, de la Escalera S, Jiménez F, Piovant M (1990) Drosophila neurotactin mediates heterophilic cell adhesion. EMBO J 9:3603-3609.

Beck K, Hunter I, Engel J (1990) Structure and function of laminin: anatomy of a multidomain glycoprotein. FASEB J 4:148-160.

Benda P, Lightbody J, Sato G, Levine L, Sweet W (1968) Differentiated rat glial cell strain in tissue culture. Science 161:370-371.

Betz WJ, Chua M, Ridge RMAP (1989) Inhibitory interactions between motoneurone terminals in neonatal rat lumbrical muscle. $J$ Physiol (Lond) 417:25-51.

Cashman NR, Boulet S, Antel J (1987) Clonal cell lines from neuroblastoma-spinal cord cell hybridization. Soc Neurosci Abstr 13: 1511.

Covault J, Cunningham IM, Sanes JR (1987) Neurite outgrowth on cryostat sections of innervated and denervated skeletal muscle. J Cell Biol 105:2479m-2488.

de la Escalera S, Bockamp E-O, Moya F, Piovant M, Jiménez F (1990) Characterization and gene cloning of neurotactin, a Drosophila transmembrane protein related to cholinesterases. EMBO J 9:3593-3601.

Dransfield I, Hogg N (1990) Regulated expression of $\mathrm{Mg}^{2+}$ binding epitope on leucocyte integrin $\alpha$ subunits. EMBO J 8:3759-3765.

Dubinsky JM, Fischbach GD (1989) A role for cAMP in the development of functional neuromuscular transmission. J Neurobiol 21: $414-426$.

Edelman G (1988) Morphoregulatory molecules. Biochemistry 27: 3533-3543.

Engvall E, Earwicker D, Haaparanta T, Ruoslahti E, Sanes JR (1990) Distribution and isolation of four laminin variants; tissue restricted distribution of heterotrimers assembled from five different subunits. Cell Reg 1:731-740.

Ginsburg S, Rahamimoff R (1983) Is extracellular calcium buffering involved in regulation of transmitter release at the neuromuscular junction? Nature 306:62-64.

Glicksman M, Sanes JR (1983) Development of motor nerve terminals formed in the absence of muscle fibers. J Neurocytol 12:661-671.

Green TL, Hunter DD, Chan W, Merlie JP, Sanes JR (1990) Expression of the synaptic cleft protein s-laminin in cell lines. Soc Neurosci Abstr 16:1011.

Greve J, Gottlieb D (1982) Monoclonal antibodies which alter the morphology of cultured chick myogenic cells. J Cell Biochem 18:221229.

Grinnell F (1978) Cellular adhesiveness and extracellular substrata. Int Rev Cytol 53:65-144.

Gutmann E, Young JZ (1944) The reinnervation of muscle after various periods of atrophy. J Anat 78:15-43.

Hemler ME (1990) VLA proteins in the integrin family: structures, functions, and their role on leukocytes. Annu Rev Immunol 8:365400.

Hortsch M, Patel NH, Bieber AJ, Traquina ZR, Goodman CS (1990) Drosophila neurotactin, a surface glycoprotein with homology to serine esterases, is dynamically expressed during embryogenesis. Development 110:1327-1340.

Hunter DD, Shah V, Merlie JP, Sanes JR (1989a) A laminin-like adhesive protein concentrated in the synaptic cleft of the neuromuscular junction. Nature 338:229-234.

Hunter DD, Porter BE, Bulock JW, Adams SP, Merlie JP, Sanes JR (1989b) Primary sequence of a motor neuron-selective adhesive site in the synaptic basal lamina protein s-laminin. Cell 59:905-913.

Hunter DD, Murphy MD, Brunken WJ (1990) The role of the extracellular matrix in photoreceptor differentiation. Soc Neurosci Abstr 16:179.

Keynes R, Cook G (1990) Cell-cell repulsion: clues from the growth cone? Cell 62:609-610.

Kimes BW, Brandt BL (1976) Characterization of two putative smooth muscle cell lines from rat thoracic aorta. Exp Cell Res 98:349-366.

Kreisverg JI, Hoover RL, Karnovsky MJ (1978) Isolation and characterization of rat glomerular epithelial cells in vitro. Kidney Int 14: $21-30$.
Krnjevic K, Morris ME, Reiffenstein RJ (1982) Stimulation-evoked changes in extracellular $\mathrm{K}^{+}$and $\mathrm{Ca}^{2+}$ in pyramidal layers of the rat hippocampus. Can J Physiol Pharmacol 60:1643-1657.

Lagenauer C, Lemmon V (1987) An L1-like molecule, the 8D9 antigen, is a potent substrate for neurite extension. Proc Natl Acad Sci USA 84:7753-7757.

Lallier T, Bronner-Fraser M (1990) Avian neural crest cells recognize multiple confirmations of laminin. J Cell Biol 111:143a.

Letourneau PC (1975) Cell-to-substratum adhesion and guidance of axonal elongation. Dev Biol 44:92-101.

Loftus JC, O'Toole TE, Plow EF, Glass A, Frelinger AL, Ginsberg MH (1990) A $\beta_{3}$ integrin mutation abolishes ligand binding and alters divalent cation-dependent conformation. Science 249:915-918.

Lupa MT, Gordon H, Hall ZW (1990) A specific effect of muscle cells on the distribution of presynaptic proteins in neurites and its absence in a C2 muscle cell variant. Dev Biol 142:31-43.

McMahan UJ, Sanes JR, Marshall LM (1978) Cholinesterase is associated with the basal lamina at the neuromuscular junction. Nature 271:172-174.

Minna J, Glazer D, Nirenberg M (1972) Genetic dissection of neural properties using somatic cell hybrids. Nature 235:225-231.

Muir D, Engvall E, Varon S, Manthorpe M (1989) Schwannoma cellderived inhibitor of the neurite-promoting activity of laminin. J Cell Biol 109:2353-2362.

Nurcombe V, Aumailley M, Timpl R, Edgar D (1989) The high-affinity binding of laminin to cells. Assignation of a major cell-binding site to the long arm of laminin and of a latent cell-binding site to its short arms. Eur J Biochem 180:9-14.

Patterson PH (1988) On the importance of being inhibited, or saying no to growth cones. Neuron 1:263-267.

Quigg RJ, Cybulsky AV, Jacobs JB, Salant DJ (1988) Anti-Fx1A produces complement-dependent cytotoxicity of glomerular epithelial cells. Kidney Int 34:43-52.

Rachinsky TL, Camp S, Li Y, Ekström TJ, Newton M, Taylor P (1990) Molecular cloning of mouse acetylcholinesterase: tissue distribution of alternatively spliced mRNA species. Neuron 5:317-327.

Reichardt LF, Tomaselli KJ (1991) Extracellular matrix molecules and their receptors: functions in neural development. Annu Rev Neurosci 14:531-570.

Reist NE, Magill C, McMahan UJ (1987) Agrin-like molecules at synaptic sites in normal, denervated and damaged skeletal muscles. J Cell Biol 105:2457-2469.

Ruoslahti E, Pierschbacher MD (1987) New perspective in cell adhesion; KGD and integrins. Science 238:491-497.

Rupp F, Payan DG, Magill-Solc C, Cowan DM, Scheller RH (1991) Structure and expression of a rat agrin. Neuron 6:811-823.

Sanes JR (1989) Extracellular matrix molecules that influence neural development. Annu Rev Neurosci 12:491-516.

Sanes IR, Chiu AY (1983) The basal lamina of the neuromuscular junction. Cold Spring Harbor Symp Quant Biol 48:667-678.

Sanes JR, Marshall LM, McMahan UJ (1978) Reinnervation of muscle fiber basal lamina after removal of myofibers. Differentiation of re generating axons at original synaptic sites. J Cell Biol 78:176-198.

Sanes JR, Engvall E, Butkowski R, Hunter DD (1990a) Molecular heterogeneity of basal laminae: isoforms of laminin and collagen IV at the neuromuscular junction and elsewhere. J Cell Biol 111:16851699.

Sanes JR, Hunter DD, Green TL, Merlie JP (1990b) S-laminin. Cold Spring Harbor Symp Quant Biol 55:419-430.

Sasaki M, Kleinman HK, Huber H, Deutzmann R, Yamada Y (1988) Laminin, a multidomain protein. The A chain has a unique globular domain and homology with the basement membrane proteoglycan and the laminin B chains. J Biol Chem 263:16536-16544.

Schubert D, Heineman S, Carlisle W, Tarikas IT, Kimes B, Patrick J, Steinbach JH, Culp W, Brandt BL (1974) Clonal cell lines from the rat nervous system. Nature 249:224-227.

Schubert D, Brass B, Dumas J-P (1986) Protein complexity of central nervous system cell lines. J Neurosci 6:2829-2836.

Schwab ME (1990) Myelin-associated inhibitors of neurite outgrowth Exp Neurol 109:2-5.

Shatz CJ (1990) Impulse activity and the patterning of connections during CNS development. Neuron 5:745-756.

Soreq H, Ben-Aziz R, Prody CA, Seidman S, Gnatt A, Neville L, Lieman-Hurwitz J, Lev-Lehman E, Ginzberg D, Lapidot-Lifson Y, Zakut $\mathrm{H}$ (1990) Molecular cloning and concentration of the coding region 
for human acetylcholinesterase reveals a $\mathrm{G}+\mathrm{C}$-rich attenuating structure. Proc Natl Acad Sci USA 87:9688-9692.

Takeichi M (1988) The cadherins: cell-cell adhesion molecules controlling animal morphogenesis. Development 102:639-655.

Tashiro K-I, Sephel GC, Weeks B, Sasaki M, Martin GR, Kleinman HK, Yamada Y (1989) A synthetic peptide containing the IKVAV sequence from the A chain of laminin mediates cell attachment, migration, and neurite outgrowth. J Biol Chem 264:16174-16182.

Tello F (1907) Degeneration et regeneration des plaques motrices apres la section des nerfs. Trab Lab Invest Biol Univ Madrid 5:117-149.

Tischler AS, Greene LA (1975) Nerve growth factor-induced process formation by cultured rat pheochromocytoma cells. Nature 258:341342.

Turner DC, Flier LA (1989) Receptor-mediated active adhesion to the substratum is required for neurite outgrowth. Dev Neurosci 11: 300-312.

Weis J, Hunter DD, Merlie JP, Sanes JR (1989) S-laminin inhibits neurite extension promoted by laminin. Soc Neurosci Abstr 15:164. Yaffe D, Saxel O (1977) Serial passaging and differentiation of myogenic cells isolated from dystrophic mouse muscle. Nature 270:725727. 